Published in final edited form as:

Biophys Chem. 2006 August 20; 123(1): 20-24.

\title{
Vesicular $\mathrm{Ca}^{2+-}$ Induced Secretion Promoted by Intracellular pH- Gradient Disruption
}

\author{
Christy L. Haynes, Leah A. Buhler, and R. Mark Wightman * \\ University of North Carolina, Chapel Hill Department of Chemistry Venable Hall, CB 3290 Chapel \\ Hill, North Carolina 27599
}

\begin{abstract}
The actions of the protonophore $\mathrm{CCCP}$ on intracellular $\mathrm{Ca}^{2+}$ regulation and exocytosis in chromaffin cells have been examined. Simultaneous fura- 2 imaging and amperometry reveal that exposure to CCCP not only perturbs mitochondrial function but that it also alters vesicular storage of $\mathrm{Ca}^{2+}$ and catecholamines. By disrupting the $\mathrm{pH}$ gradient of the secretory vesicle membrane, the protonophore allows both $\mathrm{Ca}^{2+}$ and catecholamine to leak into the cytosol. Unlike the high cytosolic $\mathrm{Ca}^{2+}$ concentrations resulting from mitochondrial membrane disruption, $\mathrm{Ca}^{2+}$ leakage from secretory vesicles may initiate exocytotic release. In conjunction with previous studies, this work reveals that catalytic and self-sustained vesicular $\mathrm{Ca}^{2+}$-induced exocytosis occurs with extended exposure to weak acid or base protonophores.
\end{abstract}

\section{Introduction}

Elevated intracellular $\mathrm{Ca}^{2+}$ triggers exocytosis from secretory vesicles. The primary route for its elevation is entry of external $\mathrm{Ca}^{2+}$ via voltage-gated $\mathrm{Ca}^{2+}$ channels[1]. However, intracellular stores of $\mathrm{Ca}^{2+}$ can also promote exocytosis [2-5]. The endoplasmic reticulum is often designated as the key dynamic $\mathrm{Ca}^{2+}$ reservoir within cells, participating in $\mathrm{Ca}^{2+}$-induced $\mathrm{Ca}^{2+}$ release and using $\mathrm{Ca}^{2+}$-regulated enzymes[6-8]. Another source of intracellular $\mathrm{Ca}^{2+}$ is the secretory vesicles where $\mathrm{Ca}^{2+}$ is sequestered into the acidic compartment and stored at high concentration by virtue of an association with chromogranin A[9,10]. In fact, nearly $60 \%$ of $\mathrm{Ca}^{2+}$ in chromaffin cells resides in the vesicular pools[11] although $>99 \%$ of the vesicular $\mathrm{Ca}^{2+}$ is highly associated within the other vesicular contents[12]. Weak bases such as methylamine and methamphetamine, as well as VMAT inhibitors, disrupt vesicular storage, promoting $\mathrm{Ca}^{2+}$ leakage from the vesicles and evoking exocytosis[13,14]. $\mathrm{Ca}^{2+}$ release from vesicles in many cell types such as insulin-secreting cells, buccal ganglion neurons, caudate nucleus synaptosomes, and neurohypophysial nerve terminals has been demonstrated[3-5]. While high affinity $\mathrm{Ca}^{2+}$ probes localized within vesicles of $\mathrm{PC}-12$ cells revealed that the vesicular compartment tracks cytosolic $\mathrm{Ca}^{2+}$ levels,[15] other vesicular compartments are known to have $\mathrm{Ca}^{2+}$ concentrations that are highly sensitive to the vesicular $\mathrm{pH}$. This vesicular $\mathrm{Ca}^{2+}$ source is particularly intriguing because it suggests that vesicles can directly induce their own release[16].

A third intracellular store of $\mathrm{Ca}^{2+}$ is mitochondria. Mitochondria accumulate $\mathrm{Ca}^{2+}$ due to a $\mathrm{pH}$ gradient between the inner mitochondrial membrane $(\mathrm{pH}=6.8)$ and the mitochondrial matrix

*rmw@email.unc.edu, Phone: (919) 843-8164, Fal: (919) 962-2388.

Publisher's Disclaimer: This is a PDF file of an unedited manuscript that has been accepted for publication. As a service to our customers we are providing this early version of the manuscript. The manuscript will undergo copyediting, typesetting, and review of the resulting proof before it is published in its final citable form. Please note that during the production process errors may be discovered which could affect the content, and all legal disclaimers that apply to the journal pertain. 
$(\mathrm{pH}=8)[17]$. Several investigators have shown that mitochondria are the chief organelle that restore elevated levels of intracellular $\mathrm{Ca}^{2+}$ to the resting concentration[18-21]. A common strategy to probe mitochondrial function is to use uncouplers, substances that dissipate the $\mathrm{pH}$ gradient, such as carbonyl cyanide $m$-chlorophenylhydrazone (CCCP). In this work, we examine the actions of the protonophore CCCP on intracellular $\mathrm{Ca}^{2+}$ regulation and exocytosis in chromaffin cells. CCCP has one extractable proton $\left(\mathrm{pK}_{\mathrm{a}} \sim 6[22]\right)$ and is able to cross lipophilic membranes in both the protonated and deprotonated forms. CCCP acts as a proton shuttle by bringing protons from the cytosol to the more basic mitochondrial matrix, thus collapsing the $\mathrm{pH}$ gradient that acts as the driving force for mitochondrial $\mathrm{Ca}^{2+}$ uptake. While $\mathrm{CCCP}$ can be used to investigate the role of mitochondrial $\mathrm{Ca}^{2+}$ regulation, recent evidence indicates that structurally similar compounds can also cause $\mathrm{Ca}^{2+}$ leakage from vesicles in PC12 cells [12]. Since vesicular $\mathrm{Ca}^{2+}$ leakage is often accompanied by dissipation of the proton gradient and self-catalyzed exocytosis[13,14], we felt it was imperative to evaluate whether CCCP could evoke exocytosis as well.

\section{Methods}

Acutely dissociated bovine adrenal medullary chromaffin cells were prepared as previously described[23]. The cells were loaded with the cytosolic $\mathrm{Ca}^{2+}$-chelating dye, fura-2 before simultaneously recording fluorescence and release with amperometry at carbon-fiber microelectrodes[23]. The cells were exposed to $2 \mu \mathrm{M}$ CCCP either by transient pressure ejection for 3 seconds or incubation for 5 or 15 minutes. Except where noted, cells were maintained in a standard buffer solution containing $10 \mathrm{mM}$ TRIS. $\mathrm{HCl}, 150 \mathrm{mM} \mathrm{NaCl}, 5 \mathrm{mM}$ $\mathrm{KCl}, 2 \mathrm{mM} \mathrm{CaCl}_{2} \cdot 2 \mathrm{H}_{2} \mathrm{O}, 1.2 \mathrm{mM} \mathrm{MgCl}_{2} \cdot 6 \mathrm{H}_{2} \mathrm{O}$, and $5 \mathrm{mM}$ glucose, adjusted to $\mathrm{pH}$ 7.4. Carbonfiber disk microelectrodes were beveled at $45^{\circ}$. Amperometry employed an Axopatch $200 \mathrm{~A}$ potentiostat with an applied voltage of $+650 \mathrm{~V}$ versus a $\mathrm{Ag} / \mathrm{AgCl}$ reference electrode. Release was stimulated with $3 \mathrm{~s}$ applications of $60 \mathrm{mM} \mathrm{K}^{+}$. Cytosolic catecholamine measurements were performed in $\mathrm{Ca}^{2+}$-free buffer using transient applications of $10 \mu \mathrm{M}$ digitonin[14].

\section{Results and Discussion \\ Transient CCCP Exposure Can Evoke Cytosolic $\mathrm{Ca}^{2+}$ and Exocytosis}

To examine the direct, short-term effects of the protonophore, CCCP was pressure ejected onto individual chromaffin cells in $\mathrm{Ca}^{2+}$-free buffer. As shown for a single example in Figure 1, a 3 second application of CCCP evoked elevated cytosolic $\mathrm{Ca}^{2+}$, measured via fura-2 fluorescence, in all cases. One source of this $\mathrm{Ca}^{2+}$ is undoubtedly intracellular mitochondria where CCCP uncouples the proton gradient that controls mitochondrial stores of $\mathrm{Ca}^{2+}$. Recent results have shown that compounds similar to $\mathrm{CCCP}$ can also displace intravesicular $\mathrm{Ca}^{2+}$, a process that appears to be controlled by a $\mathrm{H}^{+} / \mathrm{Ca}^{2+}$ exchanger[12]. Thus, raising the vesicular $\mathrm{pH}$ via CCCP would generate conditions where the chromogranin A matrix could begin to unravel, allowing vesicular $\mathrm{Ca}^{2+}$ to escape into the cytosol via the exchanger. The elevated cytosolic $\mathrm{Ca}^{2+}$ concentration was sufficient to cause vesicular release, measured by amperometry, in two out of ten cells tested in this way (bottom amperometric trace in Figure $1)$.

\section{Long-Term CCCP Exposure Increases Cytosolic $\mathrm{Ca}^{2+}$ Clearance and Release Duration}

When examined following a 5 minute incubation in $\mathrm{CCCP}(2 \mu \mathrm{M})$ in buffer containing $\mathrm{Ca}^{2+}$, levels of intracellular $\mathrm{Ca}^{2+}$ were returned to levels similar to control cells. However, spontaneous exocytotic events were occasionally observed during the CCCP incubation period (data not shown). These spontaneous events occurred at a lower frequency than stimulated events and were more common at the beginning of the incubation period than the end. More dramatic effects were seen on $\mathrm{Ca}^{2+}$ clearance following membrane depolarization. Incubation 
in CCCP increased both the cytosolic $\mathrm{Ca}^{2+}$ clearance time and the catecholamine release duration evoked by transient $\mathrm{K}^{+}$, consistent with previous results[18,21]. Specifically, responses to pressure ejection $(3 \mathrm{~s})$ of $60 \mathrm{mM} \mathrm{K}^{+}$at cells incubated for 5 minutes in CCCP (2 $\mu \mathrm{M}, \mathrm{n}=6)$ were compared to control cells $(\mathrm{n}=6)$ stimulated in the same way (Figure 2$)$. The cytosolic $\mathrm{Ca}^{2+}$ clearance in the cells exposed to CCCP had a half-width of $20.3 \pm 2.3 \mathrm{~s}$. This was almost twice as long as the $\mathrm{Ca}^{2+}$ clearance in the control cells, with a fura- 2 half-width of $9.4 \pm 1.2 \mathrm{~s}$ (Figure 2). Similarly, the $21.9 \pm 1.9 \mathrm{~s}$ duration of vesicular release from cells maintained in buffer containing CCCP was more than twice the $5.6 \pm 0.7 \mathrm{~s}$ duration observed in control cells. The increase in both the calcium clearance time and catecholamine release duration was significantly different from the control values (Mann-Whitney U-test, $\mathrm{p}<0.01$ ). Thus, during $\mathrm{K}^{+}$evoked release, we largely attribute the effect of CCCP on elevated $\mathrm{Ca}^{2+}$ and release duration to its effects on mitochondria, where its uncoupling impairs the ability to restore cytosolic $\mathrm{Ca}^{2+}$ levels. This conclusion is consistent with that of Yang and coworkers who reported that the $\mathrm{Na}^{+} / \mathrm{Ca}^{2+}$ exchanger, endoplasmic reticulum, and mitochondria work cooperatively to regulate $\mathrm{Ca}^{2+}$ near exocytotic sites but that the mitochondrial uptake is dominant when the cytosolic $\mathrm{Ca}^{2+}$ diffuses away from exocytotic sites[18].

\section{Quantal Size Decreases with Long Protonophore Exposure Time}

The role of CCCP in secretory vesicle leakage was examined by monitoring the quantal size (Q) of exocytosed catecholamines with different CCCP exposure times. Each cell was stimulated 4 times by pressure ejection of high $\mathrm{K}^{+}$with 2 minute intervals between each stimulation, and the resulting exocytotic events were recorded. Next, the cell was incubated in CCCP $(2 \mu \mathrm{M})$ for 5 or 15 minutes. After washing with CCCP-free buffer, the same stimulation pattern with high $\mathrm{K}^{+}$was applied again. To account for the variability that can exist between cells, each cell was used as its own control by normalizing amperometric spikes obtained postincubation with the spikes obtained prior to the CCCP incubation. In control cells $(n=10)$, neither 5 nor 15 minute incubations in CCCP-free buffer caused a significant change in spike half-width $\left(\mathrm{t}_{1 / 2}\right)$ or $\mathrm{Q}$ as indicated by post/pre ratios near 1.0 for all cases (Figure 3B and 3C, black bars). Ratios calculated from amperometric traces recorded before and after a $5 \mathrm{~min}$ incubation in CCCP $(n=4)$ also did not yield significantly different $t_{1 / 2}$ compared to control cells (Figure 3B, white bars). The $\mathrm{Q}$ ratios were slightly lower, but the result was not significant ( $p>0.05$ ). In contrast, $Q$ ratios calculated for cells that were incubated with CCCP for 15 minutes $(n=5)$ are significantly smaller $(0.51$ post/pre incubation) than control cell $\mathrm{Q}$ ratios (Figure 3C, white bars) while $\mathrm{t}_{1 / 2}$ ratios remain unaffected. Because there was not a significant difference between the $t_{1 / 2}$ ratios obtained following incubation with CCCP, it is clear that the lowered amounts released per exocytotic event are not due to an increased affinity between catecholamine and chromogranin A. Rather, the results are consistent with a disruption of vesicular storage following incubation with CCCP as a consequence of collapsing intracellular $\mathrm{pH}$ gradients, allowing catecholamine molecules and $\mathrm{Ca}^{2+}$ leakage. This would result in the reduced amount released in each exocytotic event, as observed.

\section{Cytosolic Catecholamine Increases Dramatically with Long CCCP Exposure Time}

Because both catecholamine and $\mathrm{Ca}^{2+}$ are highly associated within the acidic intravesicular matrix, leakage of catecholamine into the cytosol during CCCP incubation is consistent with the simultaneous release of intravesicular $\mathrm{Ca}^{2+}$ reported previously[12]. This leakage was verified by examining cytosolic catecholamine molecules after permeabilizing CCCP-exposed cells with $10 \mu \mathrm{M}$ digitonin in $\mathrm{Ca}^{2+}$-free buffer. Unlike the millisecond timescale of exocytotic release, cytosolic catecholamine liberated following digitonin permeation has a time course of several seconds (Figure 4). In control cells where CCCP was not included in the buffer, no catecholamine was detected when the cells were exposed to digitonin (data not shown), indicating low cytoplasmic catecholamine levels. However, digitonin permeabilization after 5 -minute CCCP $(2 \mu \mathrm{M})$ incubation resulted in detection of $2.1 \pm 0.5 \times 10^{7}$ cytoplasmic 
catecholamine molecules $(\mathrm{n}=7)$ and $5.5 \pm 1.0 \times 10^{7}$ cytoplasmic catecholamine molecules were detected from cells incubated for 15 minutes with the same concentration of CCCP $(n=6)$. These cytosolic catecholamine amounts are comparable to those measured when chromaffin cells were incubated with the VMAT inhibitor, reserpine[14]. Thus, the cytosolic catecholamine measurements clearly illustrate that the intravesicular contents can be displaced into the cytosol following CCCP. This extensive vesicular perturbation after 15 minute CCCP incubation is manifested by the decreased amounts released in each exocytotic event (Figure $3 \mathrm{C})$.

\section{Conclusions}

The protonophore CCCP has been a critical tool in establishing the predominance of mitochondria in restoring high cytosolic $\mathrm{Ca}^{2+}$ to resting levels[20,21,24]. Simultaneous fura-2 imaging and amperometry used in this work reveal that incubations in CCCP also alter vesicular storage of $\mathrm{Ca}^{2+}$ and catecholamine. These data clearly indicate that CCCP promotes leakage of vesicle contents into the cytosol. Indeed, the magnitude of the change in intracellular $\mathrm{Ca}^{2+}$ concentration following transient exposure to CCCP is similar to when the cells were depolarized (compare Figures 1 and 2). Despite evoking large cytosolic $\mathrm{Ca}^{2+}$ concentrations, exposure to CCCP did not always cause secretion, and it did so primarily upon the initial exposure. Elevated intracellular $\mathrm{Ca}^{2+}$ can only cause exocytosis if it occurs in close proximity to both the cell membrane and a fusion competent vesicle. Because CCCP disrupts $\mathrm{pH}$ gradients, and thus $\mathrm{Ca}^{2+}$ storage, at multiple intracellular organelles, most of which are not proximal to the cell membrane, overall intracellular $\mathrm{Ca}^{2+}$ rises but only a small portion of it is optimally positioned to induce exocytosis. Based on this work, previous results achieved with amine weak bases[14] can be further generalized to state that the weak acids as well as weak base protonophores can induce unraveling of vesicular contents. The results also show that the vesicular $\mathrm{Ca}^{2+}$ likely catalyzes and promotes self-sustained exocytosis.

\section{Acknowledgements}

This work was supported by National Institutes of Health grant NS 38879 .

\section{References}

1. Tsien RW. Calcium Channels in Excitable Cell Membranes. Ann Rev Physiol 1983;45:341-358. [PubMed: 6303205]

2. Yoo SH, Albanesi JP. $\mathrm{Ca}^{2+}$-Induced Conformational Change and Aggregation of Chromogranin A. J Bio Chem 1990;265:14414-14421. [PubMed: 2387861]

3. Troadec JD, Thirion S, Laugier JP, Nicaise G. Calcium-Induced Calcium Increase in Secretory Vesicles of Permeabilized Rat Neurohypophysial Nerve. Terminals Bio Cell 1998;90:339-349.

4. Scheenen WJJM, Wollheim CB, Pozzan T, Fasolato C. $\mathrm{Ca}^{2+}$ Depletion from Granules Inhibits Exocytosis: A Study with Insulin-Secreting Cells. J Bio Chem 1998;273:19002-19008. [PubMed: 9668080]

5. Fossier P, et al. Control of the Calcium Concentration Involved in Acetylcholine Release and its Facilitation: an Additional Role for Synaptic Vesicles? Neurosci 1998;85:85-91.

6. Rossier MF, Putney JW Jr. The Identity of the Calcium-Storing, Inositol 1,4,5-TrisphosphateSensitive Organelle in Non-Muscle Cells: Calciosome, Endoplasmic Reticulum ... or Both? Tr Neurosci 1991;14:310-314.

7. Verkhratsky A, Toescu EC. Endoplasmic Reticulum $\mathrm{Ca}^{2+}$ Homeostatis and Neuronal Death. J Cell Mol Med 2003;7:351-361. [PubMed: 14754504]

8. Kang G, Holz GG. Amplification of Exocytosis by $\mathrm{Ca}^{2+}$-Induced $\mathrm{Ca}^{2+}$ Release in INS-1 Pancreatic $\beta$ Cells. J Phys 2003;546:175-189. 
9. Videen JS, Mezger MS, Chang YM, O'Connor DT. Calcium and Catecholamine Interactions with Adrenal Chromogranins. Comparison of Driving Forces in Binding and Aggregation. J Bio Chem 1992;267:3066-3073. [PubMed: 1737762]

10. Yoo SH, Lewis MS. Effects of $\mathrm{pH}$ and $\mathrm{Ca}^{2+}$ on Monomer-Dimer and Monomer-Tetramer Equilibria of Chromogranin A. J Bio Chem 1992;267:11236-11241. [PubMed: 1597459]

11. Haigh JR, Parris R, Phillips JH. Free Concentrations of Sodium, Potassium, and Calcium in Chromaffin Granules. Biochem J 1989;259:485-491. [PubMed: 2719661]

12. Mahapatra NR, et al. A Dynamic Pool of Calcium in Catecholamine Storage Vesicles. J Bio Chem 2004;279:51107-51121. [PubMed: 15358782]

13. Mundorf ML, Hochstetler SE, Wightman RM. Amine Weak Bases Disrupt Vesicular Storage and Promote Exocytosis in Chromaffin Cells. J Neurochem 1999;73:2397-2405. [PubMed: 10582599]

14. Mundorf ML, Troyer KP, Hochstetler SE, Near JA, Wightman RM. Vesicular $\mathrm{Ca}^{2+}$ Participates in the Catalysis of Exocytosis. The Journal of Biological Chemistry 2000;275:9136-9142. [PubMed: 10734047]

15. Moreno A, et al. Calcium Dynamics in Catecholamine-Containing Secretory Vesicles. Cell Cal 2005;37:555-564.

16. Mitchell KJ, et al. Dense Core Secretory Vesicles Revealed as a Dynamic $\mathrm{Ca}^{2+}$ Store in Neuroendocrine Cells with a Vescile-Associated Membrane Protein Aequorin Chimaera. Journal of Cell Biology 2001;155:45-51.

17. Cano Abad MF, Di Benedetto G, Magalhaes PJ, Filippin L, Pozzan T. Mitochondrial pH Monitored by a New Engineered Green Fluorescent Protein Mutant. J Bio Chem 2004;279:11521-11529. [PubMed: 14701849]

18. Yang DM, Kao LS. Relative Contribution of the $\mathrm{Na}^{+} / \mathrm{Ca}^{2+}$ Exchanger, Mitochrondria and Endoplasmic Reticulum in the Regulation of Cytosolic $\mathrm{Ca}^{2+}$ amd Catecholamine Secretion of Bovine Adrenal Chromaffin Cells. J Neurochem 2001;76:210-216. [PubMed: 11145994]

19. Johnson JD, Chang JP. Calcium Buffering Activity of Mitochondria Controls Basal Growth Hormone Secretion and Modulates Specific Neuropeptide Signaling. Cell Cal 2005;37:573-581.

20. Xu T, Naraghi M, Kang H, Neher E. Kinetic Studies of $\mathrm{Ca}^{2+}$ Binding and $\mathrm{Ca}^{2+}$ Clearance in the Cytosol of Adrenal Chromaffin Cells. Biophys J 1997;73:532-545. [PubMed: 9199815]

21. Herrington J, Park YB, Babcock DF, Hille B. Dominant Role of Mitochondria in Clearance of Large $\mathrm{Ca}^{2+}$ Loads from Rat Adrenal Chromaffin Cells. Neuron 1996;16:219-228. [PubMed: 8562086]

22. Sturdik E, et al. Relationships Among Structure, Reactivity Towards Thiols, adn Basicity of Phenylhydrazonopropanedinitriles Collection of Czechoslovak. Chemical Communications 1985;50:2065-2076.

23. Finnegan JM, Borges R, Wightman RM. Comparison of Cytosolic $\mathrm{Ca}^{2+}$ and Exocytosis Responses from Single Rat and Bovine Chromaffin Cells. Neurosci 1996;71:833-43.

24. Park YB, Herrington J, Babcock DF, Hille B. $\mathrm{Ca}^{2+}$ Clearance Mechanisms in Isolated Rat Adrenal Chromaffin Cells. J Phys 1996;492:329-346. 


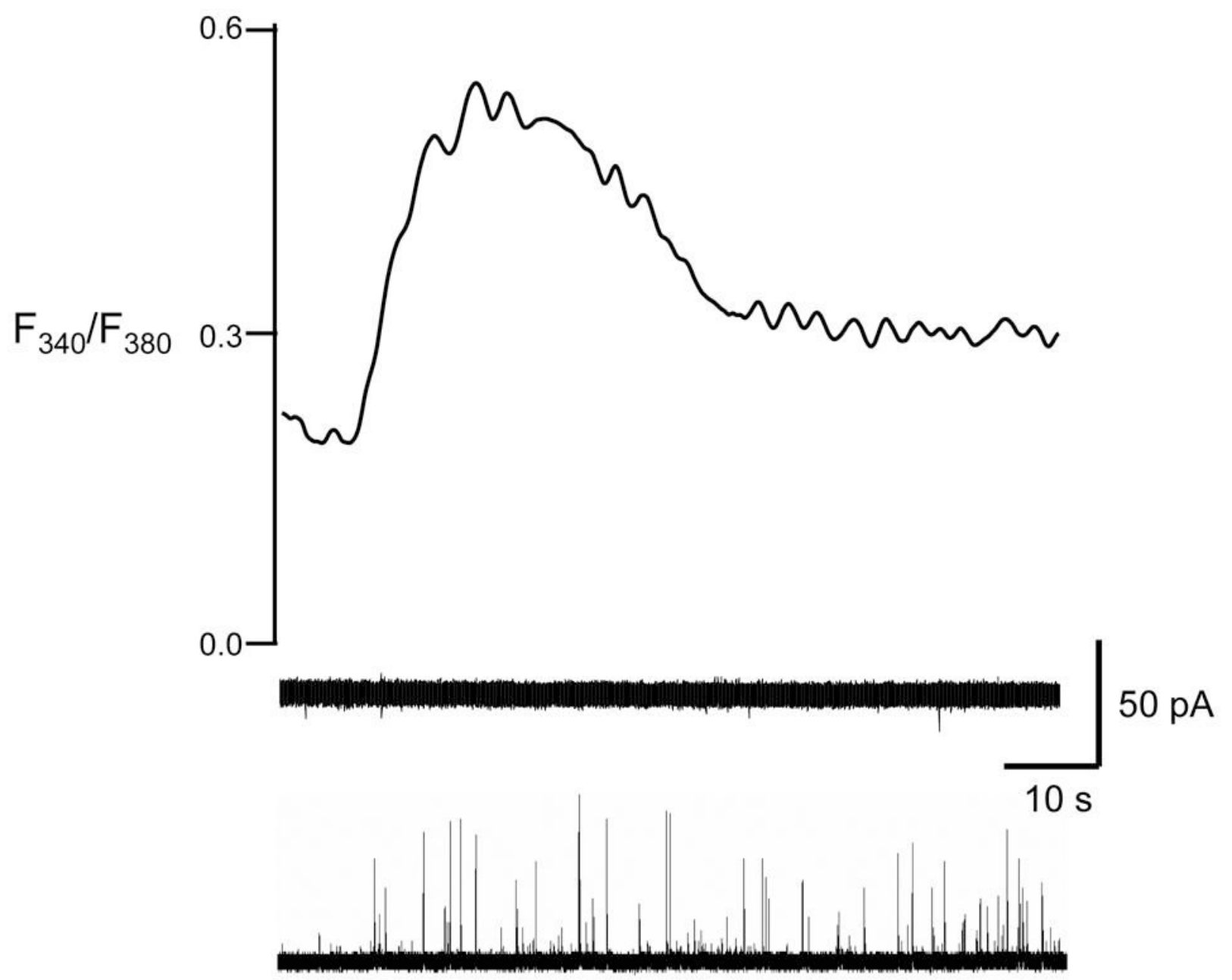

Figure 1. Amperometric and fura-2 signal traces in response to a transient application of CCCP A 3-s application of $2 \mu \mathrm{M}$ CCCP caused $\mathrm{Ca}^{2+}$ elevation (top). In 8 out of 10 cells, no release was observed (middle). In 2 out of 10 cells, the elevated $\mathrm{Ca}^{2+}$ concentration was sufficient to evoke amperometric release (bottom). The right $y$-axis corresponds to the upper trace while the scale on the left corresponds to both amperometric traces. Cells were maintained in $\mathrm{Ca}^{2+}$ free buffer. 


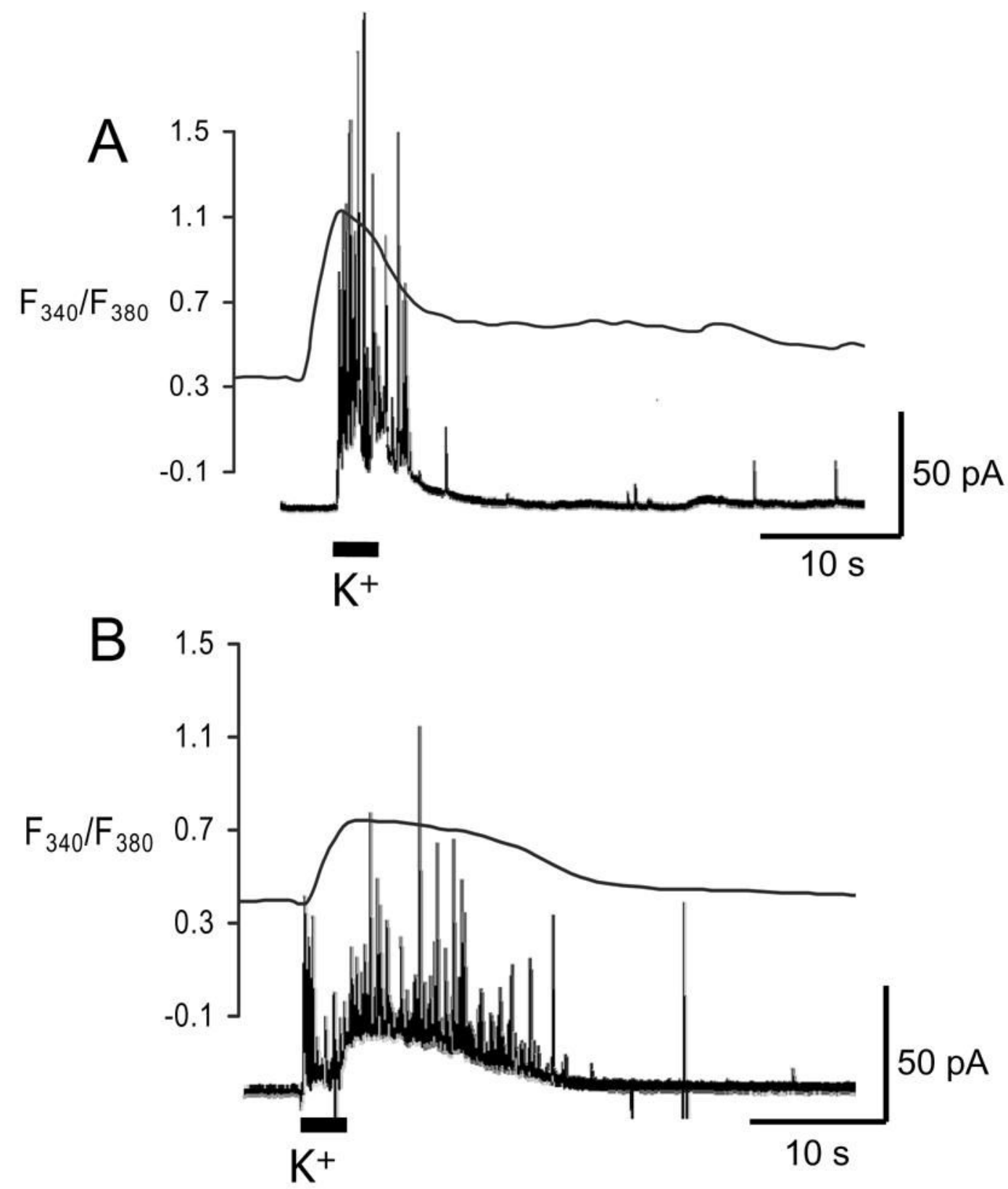

Figure 2. Amperometric and fura-2 signal traces in the presence and absence of the protonophore, CCCP

Each cell was exposed to a 3-s pressure ejection of $60 \mathrm{mM} \mathrm{K}^{+}$in $\mathrm{Ca}^{2+}$ containing buffer. Overlays of representative amperometric (left y-axis) and fura-2 (right y-axis) traces for A) untreated cells and B) treated cells. Exposure to CCCP increased both the release duration and the width at half-maximal height of the fura- 2 signal. 

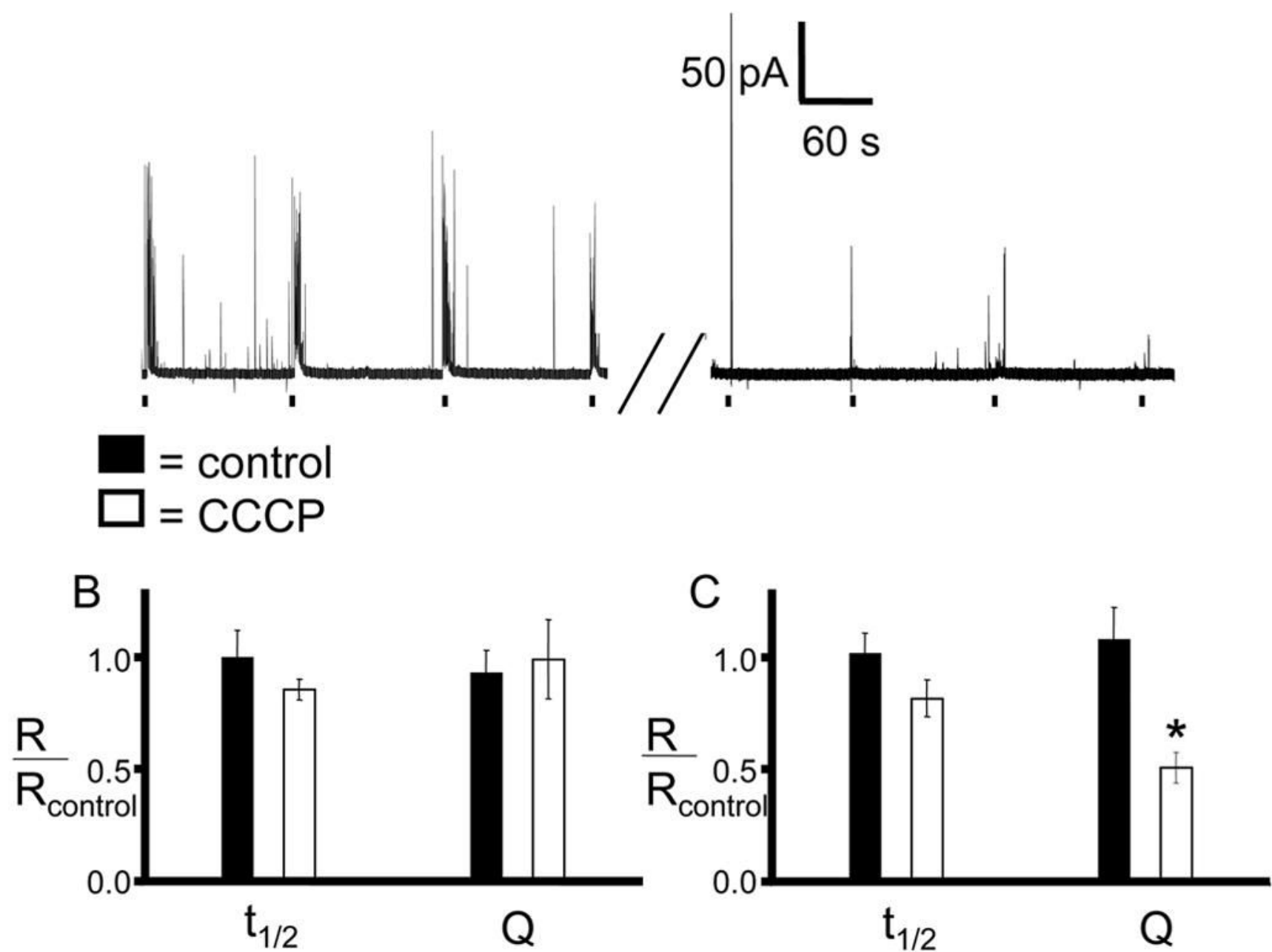

Figure 3. Amperometric detection of time-dependent depletion of epinephrine from vesicles Individual chromaffin cells were exposed 4 times to a 3 -s pressure ejection of $60 \mathrm{mM} \mathrm{K}^{+}$in a $\mathrm{Ca}^{2+}$ containing buffer. The cells were then incubated in buffer containing $2 \mu \mathrm{M} \mathrm{CCCP}$ for the indicated time. After the incubation period, the cells were washed with buffer and stimulated again using the same $\mathrm{K}^{+}$ejection pattern. Average spike parameters were then normalized by the pre-incubation values for each cell so that each cell acted as its own control. A) A representative amperometric trace of a 15 minute CCCP incubation. B) 5 minute incubation in CCCP caused no significant change in the average current spike half-width or quantal size compared with pre-incubation averages. C) 15 minute incubation causes a significant decrease in quantal size ( $\mathrm{p}<0.001$ by Mann-Whitney U-test). 


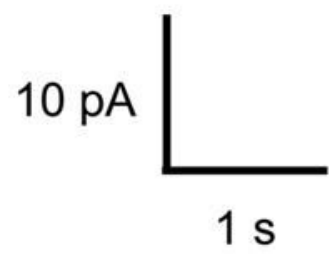

A

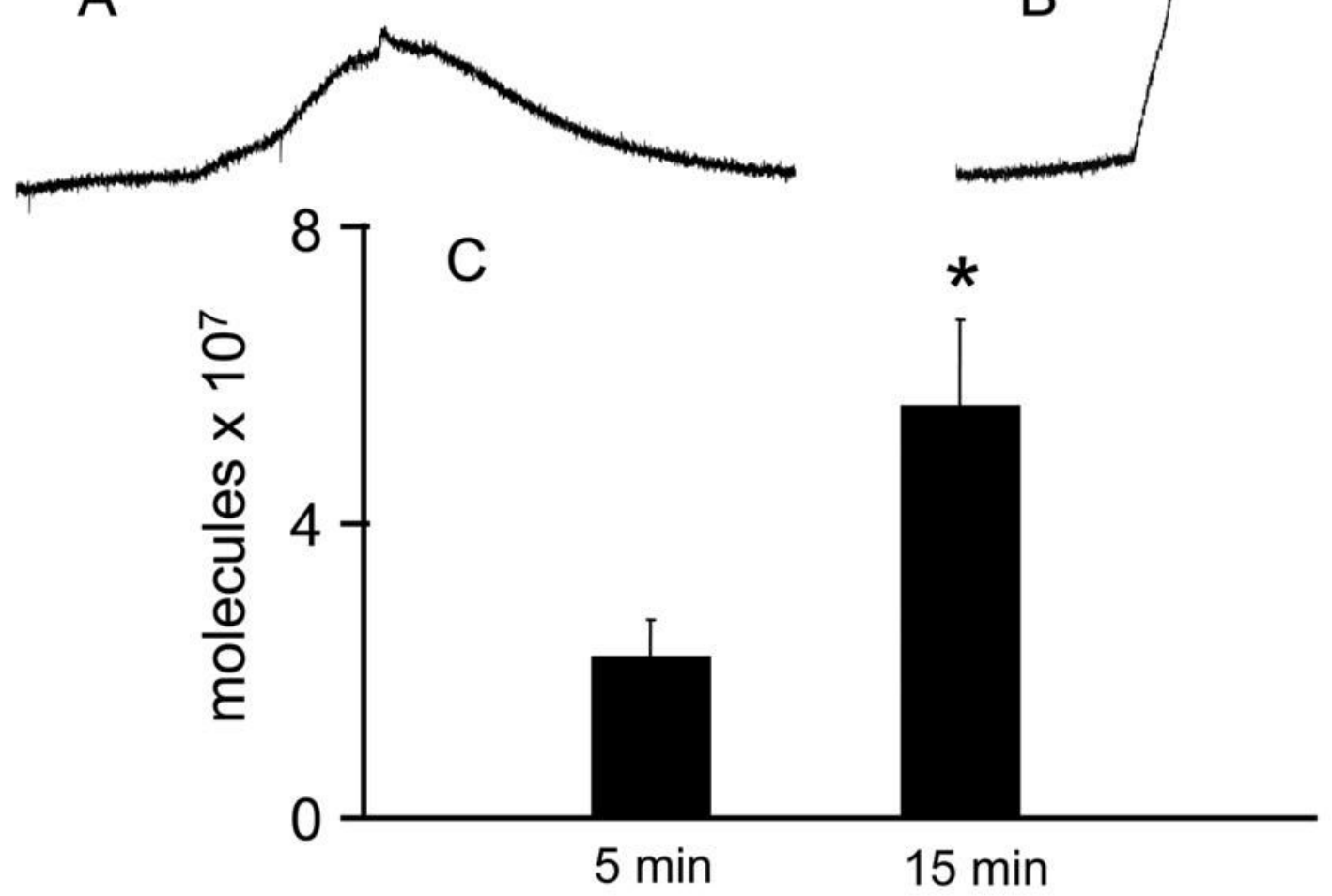

Figure 4. Cytosolic catecholamine content evaluated by digitonin permeabilization The cells were incubated with $2 \mu \mathrm{M} \mathrm{CCCP} \mathrm{in} \mathrm{Ca}^{2+}$-containing buffer for the either A) 5 minutes or B) 15 minutes. After washing and transferring to $\mathrm{Ca}^{2+}$-free buffer, $10 \mu \mathrm{M}$ digitonin was pressure ejected onto the cell. The resulting envelope is an indication of the amount of catecholamine that was present in the cytosol of the cell. C) The 15 minute incubation resulted in approximately double the amount of catecholamine molecules that were detected after a 5 minute incubation ( $\mathrm{p}<0.05$ by Mann-Whitney U-test). 